\title{
PAY-FOR-PERFORMANCE PROGRAMME IN PRIMARY HEALTH CARE: ANALYZING PERFORMANCE AND SOCIAL PARTICIPATION IN THE RIO GRANDE DO NORTE STATE
}

\author{
PROGRAMA DE PAGAMENTO POR DESEMPENHO \\ NA ATENCÃO BÁSICA À SAÚDE: ANALISANDO \\ DESEMPENHO E PARTICIPACÃO SOCIAL NO \\ ESTADO DO RIO GRANDE DO NORTE
}

Submission: $19 / 01 / 21$ Accept: $24 / 04 / 21$

\author{
Tamiris Cristhina Resende ${ }^{1,2}$ \\ Washington José de Souza ${ }^{3}$ \\ Stephen Peckham ${ }^{4}$ \\ Magnus Luiz Emmendoerfer ${ }^{5}$ \\ Marco Aurélio Marques Ferreira ${ }^{5}$ \\ 1 Centro Universitário do Leste de Minas Gerais (Unileste-MG). Coronel Fabriciano, Minas Gerais, Brazil. \\ 2 Universidade Federal de Juiz de Fora campus Governador Valadares (UFJF-GV). \\ Governador Valadares, Minas Gerais, Brazil. \\ 3 Universidade Federal do Rio Grande do Norte. Natal, Rio Grande do Norte, Brazil. \\ 4 University of Kent, Professor at London School of Hygiene and Tropical Medicine. \\ Canterbury, Kent, United Kingdom. \\ 5 Universidade Federal de Viçosa (DAD/UFV). Viçosa, Minas Gerais, Brazil.
}

\begin{abstract}
Introduction: Pay-for-performance or performance-based financing systems have been adopted worldwide in public health. Following the international trend, Brazil implemented in 2011 the National Program for Improving Primary Care Access and Quality (PMAQ).

Originality/value: This study therefore addresses how the National Program for Improving Primary Care Access and Quality contributes to the exercise of social control in Brazilian municipalities as a tool for managing public health policy.

Purpose: In this regard, the objective of this study outline connections between the performance of the health teams in the PMAQ and the participatory health councils, based on the experiences of councillors and managers from the three large municipalities in the state of Rio Grande do Norte.

Research Design: The research included semi-structured interviews with members of participatory health councils and health managers, as well as the systematization of information collected in official documents and articles about PMAQ.

Findings: It was concluded that the data collected on user satisfaction with public health services have a high potential to inform Municipal Health Councils in their role of quality control, which occurs in the three large municipalities of Rio Grande do Norte.
\end{abstract}

Keywords: pay-for-performance (P4P); public policy evaluation; Municipal Health Councils; social participation; public health 


\section{RESUMO}

Introdução: Os sistemas de pagamento por desempenho ou de financiamento com base no desempenho foram adotados mundialmente na saúde pública. Seguindo a tendência internacional, o Brasil implantou em 2011 o Programa Nacional de Melhoria do Acesso e da Qualidade da Atenção Básica (PMAQ).

Originalidade/relevância: Este estudo, portanto, aborda como o Programa Nacional de Melhoria do Acesso e da Qualidade da Atenção Básica contribui para o exercício do controle social nos municípios brasileiros como instrumento de gestão das políticas públicas de saúde.

Objetivo: Nesse sentido, o objetivo deste estudo traçar relações entre a atuação das equipes de saúde do PMAQ e dos conselhos participativos de saúde, a partir das experiências de conselheiros e gestores dos três grandes municípios do estado do Rio Grande do Norte.

Métodos: A pesquisa incluiu entrevistas semiestruturadas com membros de conselhos participativos de saúde e gestores de saúde, bem como a sistematização de informações coletadas em documentos oficiais e artigos sobre o PMAQ.

Conclusões: Concluiu-se que os dados coletados sobre a satisfação dos usuários com os serviços públicos de saúde apresentam alto potencial para informar os Conselhos Municipais de Saúde sobre seu papel no controle de qualidade, que ocorre nos três grandes municípios do Rio Grande do Norte.

Palavras-chave: pagamento por desempenho (P4P); avaliação de políticas públicas; análise de políticas públicas; Conselhos Municipais de Saúde; participação social

\section{INTRODUCTION}

Despite the lack of investments in public health, when compared with other countries, Brazil has one of the biggest public health systems in the world known as "Sistema Único de Saúde" (SUS). All the Brazilian population and foreigners that are temporarily in Brazil can access this system to receive medical assistance. The SUS was created after the Federal Constitution in 1988 as part of the legacy of the Sanitary Movement.

The SUS is also part of the prevention paradigm that is a result of the improvement of the living conditions of the population. The prevention paradigm is the opposite of the Flexnerian paradigm (biomedical) where the most important is to treat the disease. The Primary Health Care (PHC) is sustained by the prevention paradigm.

The World Health Organization $(2018$, p.5) states in the Astana Declaration that the "strengthening primary health care (PHC) is the most inclusive, effective and efficient approach to enhance people's physical and mental health, as well as social well-being and that PHC is a cornerstone of a sustainable health system". In Brazil, the PHC is offered through the SUS in almost all the municipalities by the Family Health Programme/Strategy since 1994.

Since its implementation in 1994, there has been a constant expansion of the population covered by the Family Health Strategy (FHS), but there are still gaps in the Brazilian National Health System. According to the World Health Organization (WHO) regarding the coverage of essential health services, Brazil is with approximately $77 \%$ of the population covered, while Canada and the United States lead the ranking with more than $80 \%$ of the population covered (WHO, 2018).

The Family Health Strategy is characterized by the proximity of health teams to the population living in each territory. As a result of the SUS territorialisation principle, each team is responsible for an average of 3000 people and, at most, 4000 people in a geographical area (Andrade, 2015). These teams are composed of a family doctor, nurse, nursing assistant and four or more community health assistants, which may also include social workers and dentists and provide the circumscribed population in the territory with a series of services related to primary care. 
Pay-for-performance (P4P) programs are part of the solution found by health system managers around the world to increase population access, quality, and efficiency of health services. Such programs have been adopted worldwide to induce the improvement of health systems through financial incentives, inputs or improvements in the structure. P4Ps have been implemented since the late 1990s in countries such as China (Wagstaff \& Yu, 2007); England, Wales and Scotland (Boeckxstaens et al., 2011); Australia (Cashin \& Chi, 2014) and Cameroon (De Allegri et al., 2018). Most part of these pay-for-performance programs are focused on the Primary Health Care services offered by the governments.

In the context of implementation of pay-for-performance programs in several countries, the Brazilian Ministry of Health implemented the National Program for Improving Primary Care Access and Quality (PMAQ) in 2011. The PMAQ was inspired by the "Quality and Outcomes Framework", the British experience of pay for health performance. The PMAQ was implemented with the objective of systematically evaluating the teams of professionals in the Family Health Strategy and to justify the increase in the investment of financial resources in primary health care (Saddi \& Pego, 2018). The PMAQ is probably the largest pay-for-performance program in the world, considering the number of health teams evaluated, the amount of resources invested and the number of users of the Unified Health System served by these professionals (Macinko et al. 2017).

In 2014, 4.2 billions reais were invested in the PMAQ (Macinko et al., 2017). Although it seems to be a big amount of money invested in public health, the resources invested in Conditional Cash Transference Program called Bolsa Familia was around 24.6 billion reais in 2014 (Ministério do Planejamento, 2014).

The purpose of this paper is to outline connections between the performance of the health teams in the PMAQ and the participatory health councils, based on the experiences of counselors and managers from the three large municipalities in the state of Rio Grande do Norte.

It is important to know how participatory health councils use information collected about user satisfaction in their role of overseeing public policies (Macinko et al., 2017), including the relationship they establish with the primary care teams in the evaluation performed in the PMAQ. The Brazilian Federal Constitution states that the actions and health services offered to the population must be part of an unified system built with the following guidelines: devolution, integral service focusing prevention and social participation (Brazil, 2020). And the law creating the Unified Health System (SUS) states that in all municipalities must create a Municipal Health Council providing the opportunity to the social participation and social control in the health policies (Brazil, 1990). Then, it is essential to understand how the community participation supported the PMAQ evaluation process and how the information collected during the evaluations can provide inputs to the social control exercised by the population in these democratic spaces.

The maintenance of the centralized character of the decisions, the incipience of the processes of democratization and the democratic control over the health system is a political-managerial problem (Teixeira et al., 2014). In this sense, research on social participation and social control has the potential to contribute to finding solutions that minimize managerial political problems in the management of the Unified Health System (SUS).

Thus, this article contributes to the literature regarding performance payment systems and social control based on cases of Brazilian municipalities with satisfactory performance in the PMAQ. The exercise, from the theoretical-methodological point of view, is to verify connections between PMAQ performance and the functioning of participatory health councils. 


\section{PAY-FOR-PERFORMANCE PROGRAMS IN HEALTH CARE, SOCIAL PARTICIPATION AND SOCIAL CONTROL}

Pay-for-performance programs (P4P) or performance-based financing (PBF) have been adopted worldwide in public health since the late 1990s. Although they vary in invested resources and problems they intend to solve, the objective is to improve the quality of services provided to users. Pay-for-performance programs originated from a project in Cambodia that received support from the World Bank during its implementation in Africa (Fritsche et al., 2014 apud Saddi, Peckham and Mundim, 2018). The World Bank continued to encourage P4P health programs in different parts of the world such as China with the Health VIII in 1998 (Wagstaff, Yu, 2007), and the pay-for-performance program implemented in Cameroon in 2011 (De Allegri et al., 2018).

In Brazil, the National Program for Improving Primary Care Access and Quality (PMAQ) was implemented by the Ministry of Health's Basic Attention Department (DAB) in 2011. The PMAQ was inspired by the British experience with the QOF and the pay-for-performance program implemented in the Autonomous Region of Andalusia, Spain. The participation of the Research Network on Primary Health Care, Federal Universities from various regions of the country and internationally recognized research institutions, such as the Oswaldo Cruz Foundation (FIOCRUZ), have taken place since the PMAQ formulation process until the current process of evaluation of health teams.

In the external evaluation process carried out under the PMAQ there are four components: self-assessment, performance in contracted indicators in the adhesion, performance in quality standards verified in loco and data collection regarding user satisfaction. The data collected regarding user satisfaction are not part of the final score of the teams of health professionals. However, the data collected on user satisfaction have the potential to contribute to the strengthening of social control. In Brazil, as well as in other countries that have implemented pay-for-performance systems, little is known about how such systems contribute to strengthening social control and social participation via, for example, public policy boards.

Social participation in public policies should be encouraged, as it favors transparency, stimulating the accountability of managers and contributing to relevant social demands in the governmental agenda. Social participation is included in the term "public engagement" and is related to the possibility of expressing opinions in governmental actions (Nabatchi and Amsler, 2014).

According to Fischer (2003, p. 205), citizens' participation in a democracy, is both a right and an obligation and "can contribute to the legitimacy of the development of public policies and their implementation". Social participation includes direct participation and indirect participation (Nabacthi et al, 2015). In indirect participation individuals choose representatives to act on their behalf, while in direct participation individuals are directly engaged in decision making and problem solving (Nabacthi et al, 2015).

In Brazil, democracy is semi-direct and thus combines political representation, in which citizens participate by electing their representatives by voting (indirect participation), with forms of direct participation in plebiscites, referendum and popular initiatives brought to public policy conferences and advice. Social participation can contribute to building consensus and increasing coordination in public policies. Such consensus-building makes it possible to identify and develop new ideas shared through the coordinated action of agents (Fischer, 2003).

There are other benefits of participation, such as diminishing conflicts, increasing confidence in government actions, learning about public policy problems, and clarifying possible disagreements in controversial points of view (Fischer, 2003). In addition, social participation is a way for the improvement of representative democracy to improve the instruments of control of pay-for-performance pro- 
grams in public health.

The word control came from the French term "contre role" and Latin medieval evolving in 1611 to a meaning close to that of domain, government, supervision, and verification (Guerra, 2005). There are several typologies for defining control in public administration. Regarding the positioning of the controlling organ, for example, the control can be defined as internal or external. Thus, internal control is that performed by an organ in the same hierarchical structure, which may refer to administrative controls or hierarchical control (Lima, 2018). External control is characterized by jurisdictional, political, or technical control (Lima, 2018). Regarding the controller's position, the social control, exercised by the participation of the company, can be considered external control.

Social control is a type of control of governmental actions that can be exercised by citizens in the formulation, implementation, and evaluation phases of public policies and in the supervision of government acts. Participation is one of the constitutional guidelines that guides the Unified Health System (SUS) in Brazil. In addition, the 1988 Federal Constitution institutionalizes public policy management boards at the federal, state, and municipal levels as areas of social control.

The Participatory Health Councils are spaces for the participation of multiple actors (collegiate bodies) in the Unified Health System (Brasil, 1990). The councils are permanent instances of social deliberation composed of representatives of government, service providers, health professionals and users. As far as the PMAQ is concerned, Participatory Health Councils should be informed about the municipality's health team adhesion to the pay-for-performance program. In addition, in the external evaluation phase of the health teams, it is demanded the collection of information to perform the evaluation of user satisfaction, which can be used as an instrument for social control carried out by the participatory health councils.

Studies on the Brazilian pay-for-performance programme have been published internationally and nationally. In the international literature, experts present an analysis of the PMAQ with recommendations for the program to achieve its objective of improving the quality and access of primary care (Macinko et al., 2017). In the national literature, there are studies that focus on parts of the assessment process such as self-assessment (Cardoso et al., 2015); external evaluation (Matta-Machado et al., 2016; Fontana et al., 2016) and user satisfaction (Protasio et al., 2017a; Protasio et al., 2017b). In addition, there are authors who deal with the evaluation of the PMAQ adherence process (Chimara et al., 2013); evaluation of the PMAQ implementation process (Linhares et al., 2014) and understand the PMAQ as an innovation (Uchôa et al., 2018).

In addition, there are studies such as Lemos et al. (2018) that mention the possibility of the PMAQ contributing to the strengthening of Social Control by the Participatory Health Councils. In a study carried out in the Northeast of the State of Minas Gerais with data from the PMAQ self-assessment part, in about $50 \%$ of the municipalities there was a recognition that municipal management did not support social participation and social control (Cardoso et al., 2015). In our search of the literature we did not find any studies dealing specifically with the social control carried out by the Municipal Health Councils and the PMAQ.

\section{RESEARCH DESIGN AND METHODS}

It is important to highlight that this study is part of a doctoral thesis. The main author remained one year and ten months in the research field collecting data. This includes a period of six months abroad in United Kingdom where it was realized an international data collection comparing pay-for-performance programmes in UK and Brazil. 
The first version of this paper was presented during the 4th International Conference on Public Policy in 2019, Montreal, Canada. All the comments received during the paper presentation were considered by the authors.

This is a multiple case study (Gustafsson, 2017) on social control in a pay for performance program based on the empirical data collection in three municipalities of Rio Grande do Norte with a population equal to or greater than 100 thousand inhabitants, as showed in figure 6 . These three municipalities belong to stratum 5 and 6 in the PMAQ's evaluation which means they have great population and better income. In the field, semi structured interviews were applied with councillors from the Municipal Health Councils.

The PMAQ evaluation has a set of indicators in areas such as Women and Children health. However, it is important to highlight that the performance analyzed here is overall performance in all the assessment with more than 900 questions.

The performance results analyzed in this paper were extracted from the first and second evaluations of the Primary Health Care teams' part of the PMAQ in Rio Grande do Norte State. The results were accessed through the Law of Access to the Information in a request directly to the Ministry of Health. The Ministry of Health sent the results to the researchers in Excel spreadsheets. The data received were organized by health team. Then, the researchers consolidated the data for each municipality in this study in order to obtain the average performance.

In addition, it was conducted interviews with health managers in the city of Mossoró, Parnamirim, Natal, and a PMAQ's manager in the Ministry of Health in Brasilia totaling twelve informants.

Table 1- List of the interviews

\section{Code}

PMAQ's manager

Councillor 1- Mossoró

Councillor 2-Mossoró

Councilor 3- Mossoró

Councillor 4-Parnamirim

Councillor 5-Parnamirim

Councillor 6- Parnamirim

Councillor-7 Natal

Councillor 8- Natal

Councillor 9- Natal

Manager 2- Parnamirim

Manager 1-Parnamirim

Source: Research Data

\section{Institution}

Ministry of Health

Mossoró's Municipal Health Council

Mossoró's Municipal Health Council

Mossoró's Municipal Health Council

Parnamirim's Municipal Health Council

Parnamirim's Municipal Health Council

Parnamirim's Municipal Health Council

Natal's Municipal Health Council

Natal's Municipal Health Council

Natal's Municipal Health Council

Municipality of Natal

Municipality of Parnamirim
City/State of the
interview
Brasília (DF)
Mossoró (RN)
Mossoró (RN)
Mossoró (RN)
Parnamirim (RN)
Parnamirim (RN)
Parnamirim (RN)
Natal (RN)
Natal (RN)
Natal (RN)
Natal (RN)
Parnamirim (RN)

At least three health councillors were chosen, respecting the diversity by segment represented in the Participatory Health Council. This ensured the various stakeholders/interests represented within each municipal health council were considered. The snowball technique was used to choose the members of the three councils (Goodman, 1961).

The municipalities are Natal (877640 inhabitants), which is the State capital, Mossoró (259.815 inhabitants) and Parnamirim (202.456 inhabitants) (Brazilian Institute of Geography and Statistics, 2018). Natal is the capital of the State and the most populous municipality. The coastal 
municipality of Parnamirim is bordered by the municipality of Natal. Mossoró, in turn, is the second largest municipality and is located at the western side of the State. The specification of this population (three cases) reduces variations and helps to define the limits for the generalization of the findings (Eisenhardt, 1989).

Figure 1- Rio Grande do Norte State's map with the municipalities above 100 thousand inhabitants

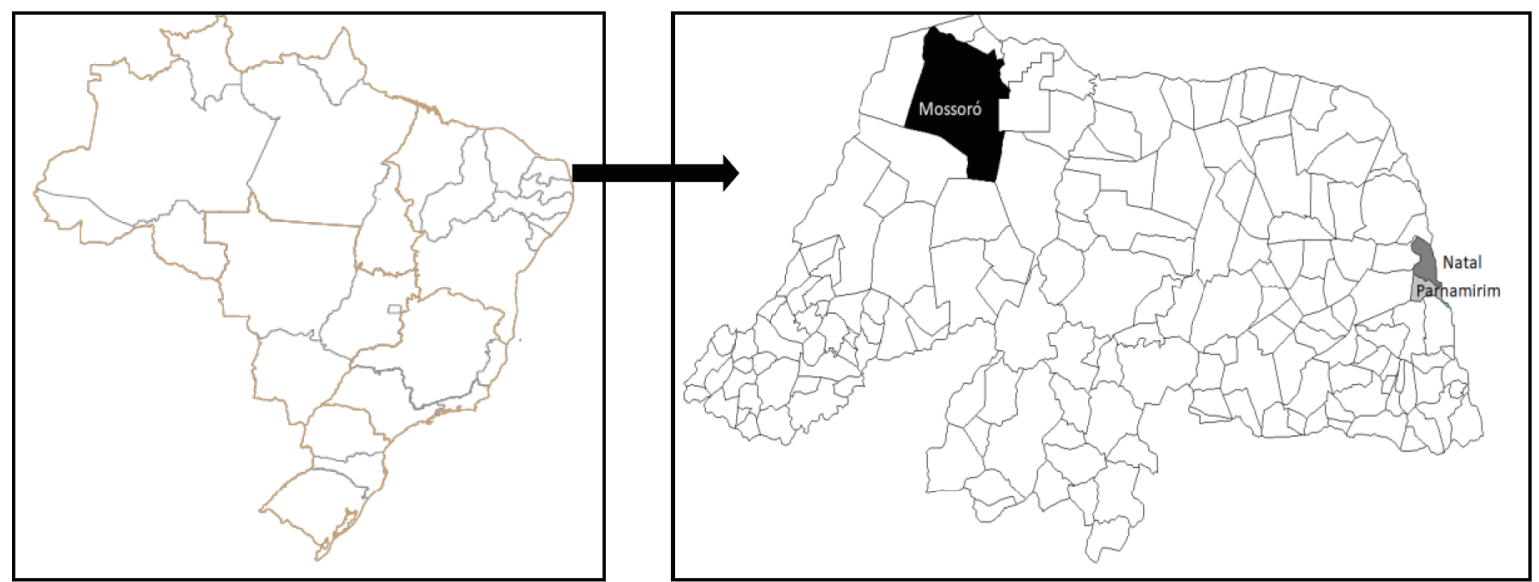

Source: Research data

Results from the first (November 2011 to June 2013) and second (June 2013 to September 2015) PMAQ evaluation cycles were included in the analysis. The analysis was carried out to answer this question: can connections be established between the performance of the teams in PMAQ and the functioning of municipal health councils in large municipalities from the experiences of counselors and managers?

The data on the performance of the teams were obtained through a request for access to the information directed to the Department of Primary Health Care of the Ministry of Health. Data related to the coverage and the amount of financial resources that each municipality received were obtained from the website of the Department of Primary Health Care in the Ministry of Health.

After the data collection, we carried out a data analysis in two categories that merged from the literature: performance of teams in PMAQ and Social Participation and Social Control in the PMAQ.

\section{PERFORMANCE OF HEALTH TEAMS IN PMAQ}

The Ministry of Health conducts evaluation and payment according to the teams' performance. However, resources are not transferred directly to the teams, but to the municipality, managed by the Municipal Health Department which then have local discretion about how to invest PMAQ resources to develop actions related to primary care at the local level. Some Brazilian municipalities provide bonuses according to performance for local health teams, however, Macinko et al. (2017) point out that little is known about how municipal managers invest the resources from the $P M A Q$, which teams receive the bonuses and how the distributed bonuses are related to the total amount of funds received.

It is important to note that there is no uniformity in the management of resources received through the PMAQ by the municipalities studied in this article. In the municipality of Mossoró, resources are apportioned as follows: $20 \%$ in primary health care costs and $80 \%$ are allocated to health 
professionals as performance bonuses (Mossoró, 2015). In this municipality, there is a difference of $42 \%$ (forty-two percent) between the amount of resources destined to the payment of bonuses for higher and middle level professionals (Mossoró, 2015). The apportionment carried out in the municipality of Mossoró privileges professionals with a higher level of education, in addition to distributing bonuses to teams with better performances.

In the municipality of Parnamirim, 50\% (fifty percent) of the resources are applied to the cost and the other $50 \%$ (fifty percent) are passed on monthly as a performance bonus to the health professionals of the teams evaluated (Parnamirim, 2015). In Natal, 60\% (sixty percent) is allocated to costing actions and $40 \%$ (forty percent) to pay bonuses to health professionals from primary care teams (Natal, 2018).

In Natal, bonuses are distributed twice a year, while in Mossoró and Parnamirim, they are distributed monthly. The municipal laws that regulate the allocation of PMAQ resources in Parnamirim and Mossoró were enacted in the last quarter of 2015 and, in Natal, only in early 2018. The social control carried out by the Municipal Health Councils of Parnamirim and Mossoró played an important role regarding the pressure to Legislative Power create a legislation regulating the use of resources.

In Natal, there was no decisive influence of the council. The promulgation of Law for the regulation of the PMAQ and organization of the apportionment of resources in Natal happened three years after the promulgation of the other two municipalities, although with transfers from the Ministry of Health since 2013. This fact happened because, until 2018, according to the interviews, managers from the municipality of Natal chose to invest the resources of PMAQ fully in health costs, which did not include payment of bonus.

During the process of evaluating the quality of health services provided by the Family Health Strategy teams, municipalities are separated into six strata that vary according to the Gross Domestic Product(GDP), demographic density, the percentage of the population with health insurance, the percentage of the population receiving conditional cash transferences such as Bolsa Familia and the percentage of the population in extreme poverty. Thus, the performance of family health teams is only compared to the performance of teams from the same stratum. Only Natal belongs to stratum 6 (municipalities with population above 500 thousand inhabitants). In stratum 5 (municipalities with population between 100 and 500 thousand inhabitants) are the municipalities of Parnamirim and Mossoró.

The total received by the municipalities in the PMAQ varies according to performance in the external evaluations. In the first cycle, Rio Grande do Norte received around US\$612615 (US\$1=R\$3,90) from the PMAQ. The municipalities of Parnamirim, Mossoró and Natal received together US\$60923 in the first cycle, which corresponds to approximately $10 \%$ of the resources in health budget destined to the entire state. 
Figure 2- Amount of resources received by municipalities in the PMAQ Total (US\$)

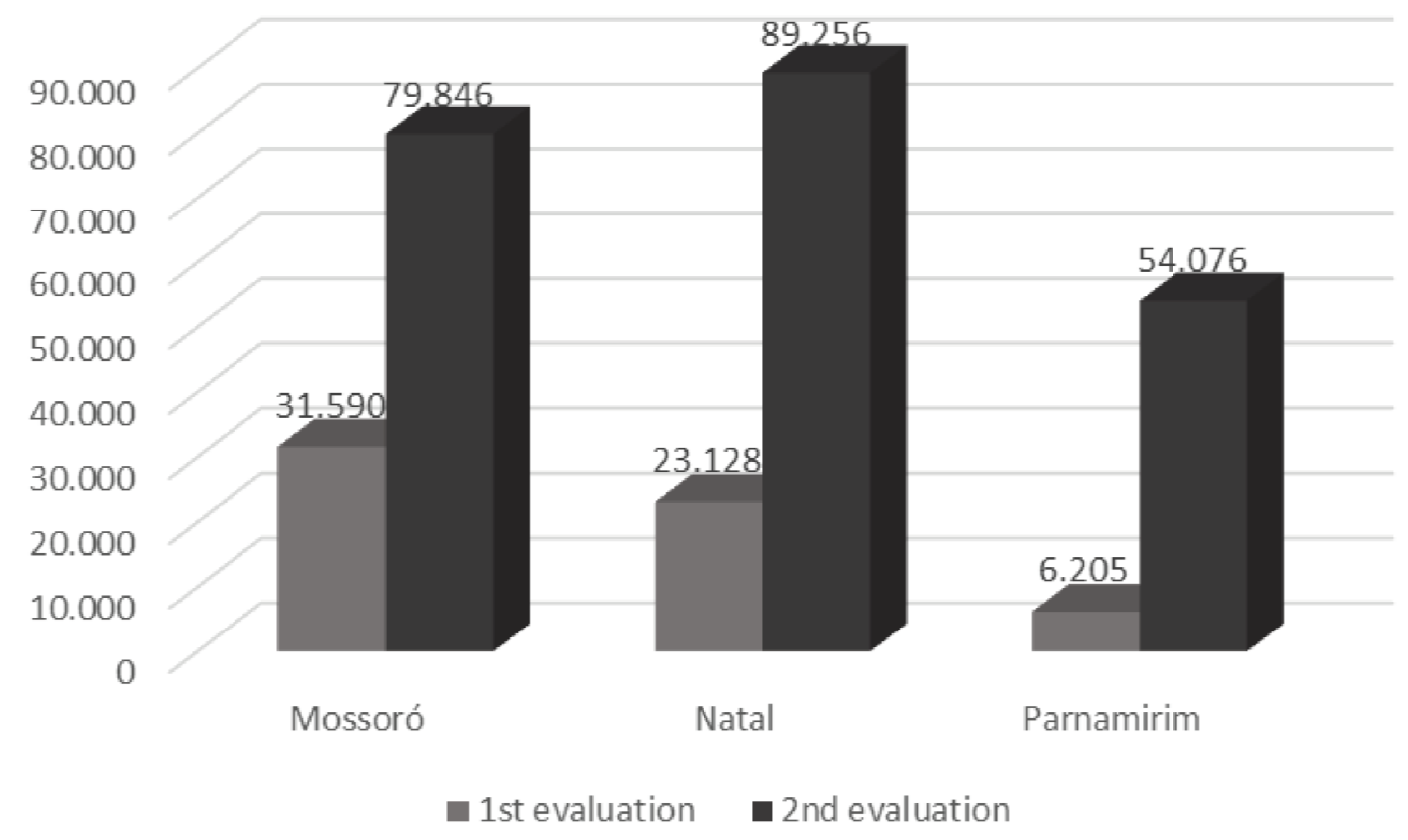

Source: Ministry of Health

The analysis of the municipalities' performance studied in this article shows that the evaluation process carried under PMAQ is supporting the improvement of the health team's performance in Rio Grande do Norte. In the first cycle, which occurred between 2011 and 2013, approximately $63 \%$ of the teams in the municipality of Mossoro achieved "median or below average" performance and $38 \%$ of the teams performed "above average" performance, as we can see in Figure 9 . In the second cycle, approximately $36 \%$ of the teams scored "median or below average", while $47 \%$ of the teams scored "above average" and $18 \%$ of the teams scored "high performance", as showed in figure 2. In this sense, it is observed that the performance of the basic health and oral health care teams improved after the implementation of the PMAQ.

In the municipality of Parnamirim, approximately $40 \%$ of the teams achieved "Median or below average" performance in the first PMAQ evaluation, while $60 \%$ of the teams scored "above average". In the second cycle, $29 \%$ of Parnamirim's teams scored "average or below average", $58 \%$ of the teams had "above average" performance and $13 \%$ of the teams scored "high performance". Like the municipality of Mossoró, it was observed that the teams improved the performance between one cycle and another in Parnamirim.

In terms of amount of money received by each team in the municipalities, in the municipality of Mossoró each health team received in average US\$790 in the first evaluation and US\$1661 in the second evaluation.

The health teams in Natal received an average US\$298 in the first evaluation and an average of US\$330 in the second evaluation. In Parnamirim, each health teams received US\$620 in the first evaluation and US\$712 in the second evaluation. 
Figure 3 - Health teams' performance in the First PMAQ Evaluation

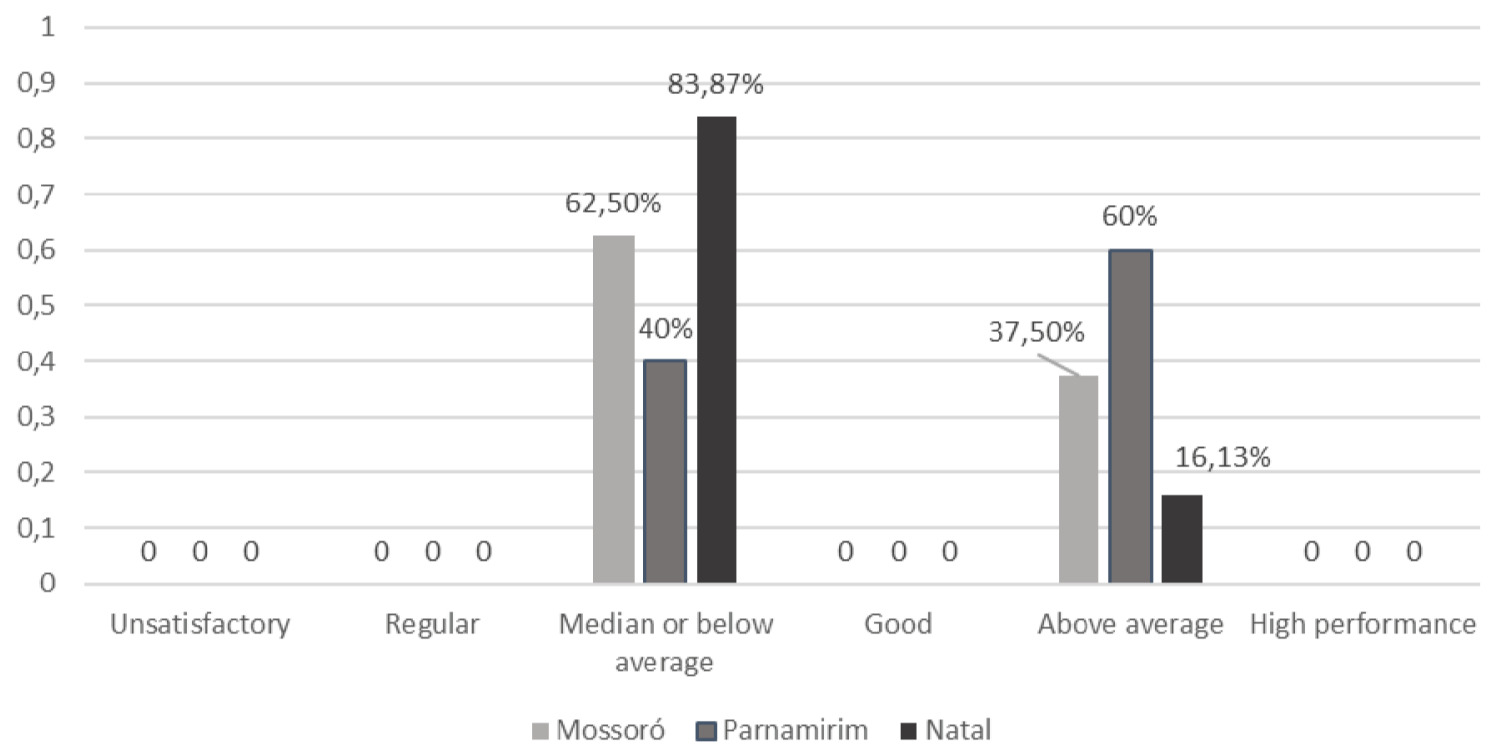

Source: Ministry of Health

Regarding the performance of the Natal's health teams, in the first cycle of PMAQ, 84\% of the teams presented "median or below average" results and $16 \%$ presented "above average" results. In the second cycle, Natal's health teams showed improvement, since $78 \%$ had a "median or below average" result, $21 \%$ had an "above average" result and approximately $0.92 \%$ had a "high performance" result. Despite the improvement, there is still poor performance.

Figure 4 - Health teams' performance in the Second PMAQ Evaluation

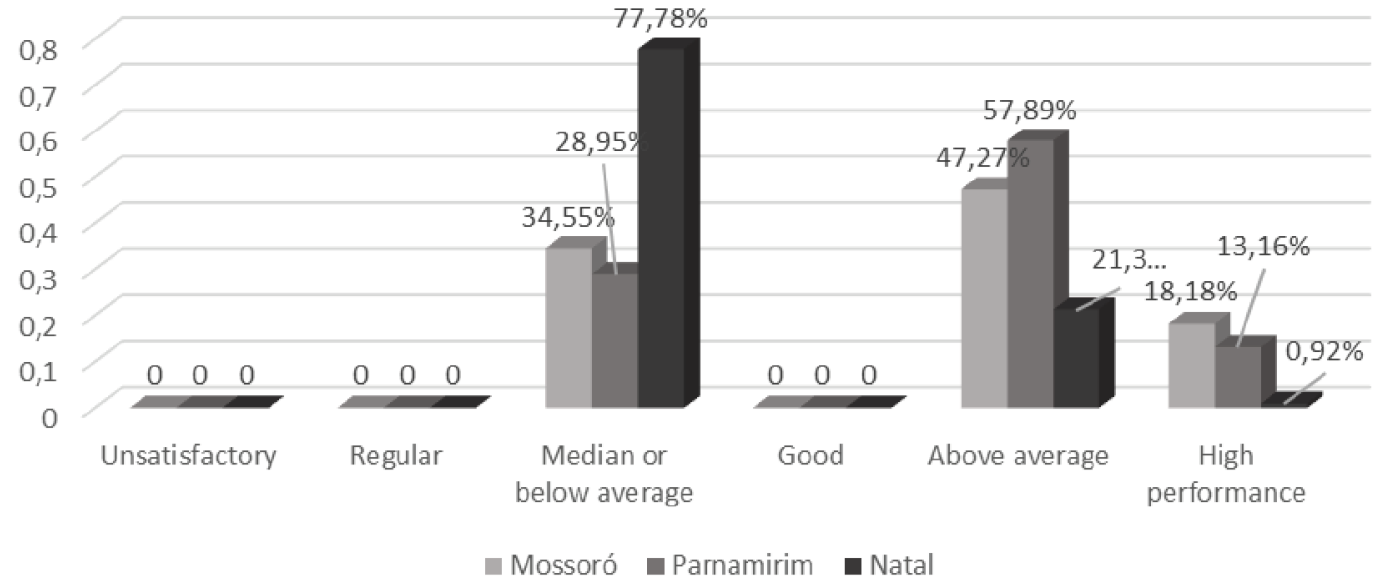

Source: Ministry of Health

As previously mentioned, the actions of the participatory health councils of Parnamirim and Mossoró contributed to the regulation of the use of the resources of the PMAQ in these municipalities. In addition, participatory health councils worked to ensure that most of the resources were allocated to health teams. Observing the data in figure 4, we can conclude that the municipalities that invested most of the resources in bonuses for the health teams were able to obtain the best results in terms of performance. In the next section we will carry out an analysis about social control 
in the PMAQ.

\section{SOCIAL PARTICIPATION AND SOCIAL CONTROL IN THE PMAQ}

Democracy in Brazil is semi-direct, so citizens can participate indirectly or directly in the conduct of public policies. Social participation through municipal health councils is a type of direct participation (Nabacthi et al., 2015). In the context of the evaluation of the PMAQ, the council is primarily responsible for monitoring resources and mediating conflicts.

Regarding the inspection of PMAQ activities, in the municipality of Parnamirim, for example, the Participatory Health Council is part of a commission that supervises the apportionment and transfer of resources to health professionals as a bonus for performance. In the municipality of Natal, for example, this apportionment began to be realized approximately three years after the beginning of the apportionment of the municipality of Parnamirim. In this sense, participatory health councils are important in building consensus and in developing the idea that resources received by the municipality should be prorated among health professionals and health managers:

\footnotetext{
"The PMAQ resources only started to be prorated in the municipality based on the demands of the Municipal Health Council. If we had not awakened to this, no one would have known what was being done with the PMAQ resources. The PMAQ resource was transferred from the federal government to the municipality of Parnamirim, but it did not reach the health teams, and nobody knows where this resource was being invested" (Councillor 4-Parnamirim city).
}

Among the suggestions for improvement, the councilors mentioned the creation of an internal monitoring and control committee of the PMAQ in the municipality involving the participation of community and key stakeholder representatives. This action happens formally only in the municipality of Parnamirim, since Mossoró and Natal do not have specific committees to follow the PMAQ. These commissions could assess the situation of the municipality before the Ministry of Health.

\footnotetext{
"Another suggestion would be for PMAQ to establish that municipalities create monitoring and internal control commissions. (...) If the Ministry's evaluation is every two years, the evaluation of the municipality could be annual or every six months. With that, the commission would have a list of the goals that were not achieved and it could point out where the municipality could improve" (Councillor 5 -Parnamirim city).
}

This commission could be useful for clarifying possible disagreements in controversial points of view and it could also helps the Primary Health Care teams to improve the quality of the servicers offered to population.

In the legal guidance that regulates the PMAQ in the municipality of Parnamirim, the creation of a permanent committee composed of four members is planned to follow the scope of the contracted indicators in the PMAQ. The Parnamirim's participatory health council maintains a representative in this permanent committee to monitor and supervise the actions of health managers and monitor the performance of the Family Health Strategy teams.

The commission in the municipality of Parnamirim is one of the examples of how social control favors the transparency and efficiency of public policies. This commission acts to verify irregularities, such as the payment of bonuses to employees who were not part of the primary care teams and the Family Health Strategy. 
In the legislation that established the PMAQ, there is an indication that the teams must communicate their adhesion to the program to the participatory health council (Ministry of Health, 2011). In all the municipalities, this obligation was observed. In figure 5 is possible to observe the participation process of Municipal Health Councils in the PMAQ:

Figure 5 - Participation process of Municipal Health Councils in the PMAQ

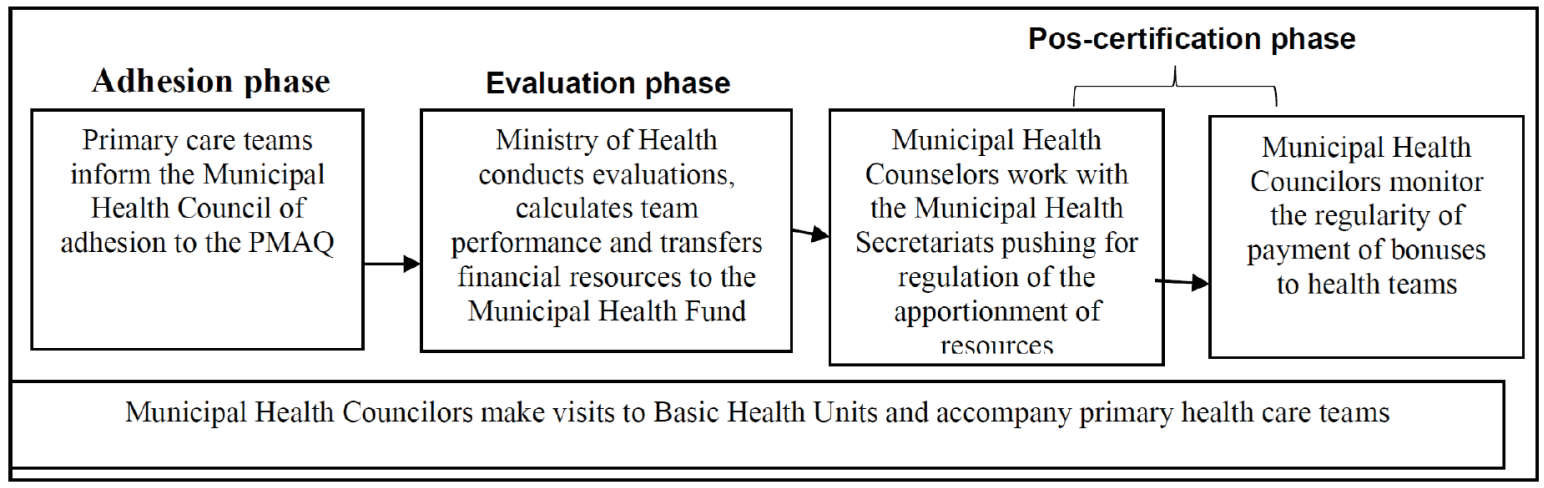

Source: Research Data

The PMAQ is evaluated by members of the councils as a positive tool and contributed to the advancement of primary care in municipalities. Among the strengths of the PMAQ were mentioned in the interviews: I) the creation of a productivity bonus in the municipalities and the possibility of linking this bonus with the performance of health professionals; II) the mobilization of the professionals in offering a quality service in the evaluation year.

In all participatory health councils analyzed, there was a greater participation of the groups representing the users of public health services and health workers. The health workers with the highest participation in the observed municipal councils were the Community Health Agents. Community Health Agents are part of the Family Health Strategy teams and work in the territory making home visits to the families.

In such a context, PMAQ has the potential to strengthen participatory approaches to social control in Brazil. The information collected in the external evaluations provide valuable information for participatory health councils to exercise their oversight role. Both councillors and health managers interviewed in this study have a positive idea about PMAQ:

"The PMAQ gave an injection of encouragement to the workers at the top to organize what they failed to organize at times like the question of organizing the unit itself" (Councillor 1Mossoró city)

"PMAQ is nothing more than what professionals already have to do. The PMAQ is nothing more than organizing your work process so that we can assess an improvement in the quality and access to primary care. There is nothing more, no more assignments. These are standards that a health unit must follow and the PMAQ is an incentive for us to increase that population's access. PMAQ is very good at motivating teams" (Health Manager- Natal city)

PMAQ is not a program that incentivizes a total change in the health care process, it is a program designed to give support to the health teams offer services to the population following the best practices already known in public health. 
In particular, the information collected about user satisfaction could be used to inform the Municipal Health Councils actions. Protasio et al. (2017a) identified that the main factors influencing a positive evaluation of the user regarding health services in all regions of Brazil are the user to solve their problems in the Health Unit and feel respected by health professionals.

Despite the difficulties and limitations of the Unified Health System, the population perceives in a positive way the attention it receives from the health teams (Abreu et al., 2018). Abreu et al. (2018) still show that there is a positive relationship between users' perception regarding accessibility, completeness, longitudinally and coordination of care and services provided by health professionals.

Although the perception of users regarding the quality of basic care in Brazil is positive, there are conflicts and issues within the PMAQ that need to be rethought by health managers so that social inequalities are not deepened in Brazil. According to the PMAQ's manager at Ministry of Health:

\footnotetext{
"There is no action to avoid the side effects as the depth of social inequalities. We are currently discussing the redesign of the PMAQ for the next cycle and we are discussing the introduction of equity mechanisms. We are very concerned about this in this fourth cycle that will begin because we realize that the PMAQ to some extent reproduces inequities. He favors those who are already better".

(PMAQ's manager- Ministry of Health)
}

Counsellors interviewed pointed another weaknesses in the PMAQ: (i) discretion in the use of resources from the federal government is a source of conflict between municipal managers and health professionals; II) the absence of clear goals, since the Ministry of Health does not divulge which of the indicators evaluated contribute more to the performance; III) the calculation of the performance of the teams is also conditioned by the infrastructure conditions on which the teams cannot act, since it is the responsibility of the health managers. According to the councillor 7 from the municipality of Natal:

\footnotetext{
"PMAQ ends up being a source of resources for management. And workers understand that it is more demanding and more responsibility on their backs. It is as if the PMAQ was something distant from the work process. Often, the PMAQ does not assess concrete conditions. The apportionment is not equated to the work of each one within the team" (Councillor 7-Municipality of Natal).
}

Health teams are evaluated for performance, but unlike in the private sector, the bonus for performance excellence or the penalty for poor performance does not go directly to the teams. Municipal health managers receive the financial resources of the federal government that are designated for PMAQ. And these managers have the freedom to invest resources as they see fit, such as investment in infrastructure or bonuses to employees (Macinko et al., 2017). However, health professionals are in conflict with health managers because the professionals would prefer most of the resources to be allocated for the payment of bonuses.

In the three municipalities studied in this article, a disparity was observed regarding the decision-making about the investment of resources. Macinko et al. (2017) notes that little is known about how municipalities invest resources from government. In this study we found that in Mossoró, $80 \%$ of resources were designated for health professionals, while Parnamirim paid $50 \%$ of resources in bonuses and Natal distributed $40 \%$ of the resources to professionals. The municipal councils of health have representatives of health professionals as members, so it was observed that in the cases analyzed the councils defend the interests of these professionals by a greater percentage in the distribution of resources - although to varying degrees. In addition to professional/manager conflicts 
the disparity in the distribution of bonuses among health professionals also gives rise to conflict.

In Mossoró, where health professionals received the highest percentage of bonuses in this study, the teams achieved the best performance among the three municipalities. In turn, in Natal, where the lowest bonus was paid, the teams had the lowest performance in the two cycles analyzed. Therefore, there would appear to be a relationship between the payment of bonuses to health professionals and performance in the cases in this study. However, to determine whether this is a general phenomenon further research is needed, not only with regard to the finding of such a direct relationship from a quantitative analysis contemplating a greater number of municipalities, but also exploring the explanatory motives of the phenomenon through more in-depth research.

The conflict over resource allocation reveals the complexity of public health challenges to be overcome in Brazil. From the point of view of municipal managers, the resource received through $P M A Q$ represents significant resources to alleviate the lack of resources to finance health services in Brazilian municipalities. On the other hand, health professionals perceive the PMAQ resource as an opportunity to have recognition for the service provided and as a way of increasing their incomes. From the point of view of managers of the Ministry of Health, the granting of freedom to managers for the use of resources is based on the view that Brazilian municipalities have differences in relation to public health problems and that a single solution would not be the best improve the quality of public health.

Similar to pay-for-performance programs in other countries, PMAQ may have undesired consequences depending on the strategy adopted by municipalities in program management (Macinko et al, 2017). In all municipalities studied, there was a higher bonus for the best performing teams in the PMAQ evaluation. In turn, lower performers received fewer resources. This strategy may favor the deepening of social inequality in the country (Macinko et al., 2017), since the poor performers may be in areas where the social problems are bigger and the working conditions of the health teams are more precarious conditions.

\section{FINAL CONSIDERATIONS}

The findings of this study suggest that PMAQ has a high potential for strengthening social control in primary health care in Brazil. The data collected about user satisfaction, the structure of the Primary Care Health Units and the work process of the Family Health Strategy teams provides valuable information to support greater social control of the delivery of public health services. In this sense, training actions are necessary to enable the councilors to know about the indicators and the evaluation process carried out in the PMAQ and how they can access the performance data of the municipal teams.

Our study also suggests that the data collected in pay-for-performance programs can be a valuable resource for improving participation and social control, both in developed and high-income countries. In terms of the performance of health teams, our findings demonstrate that social control is one of the factors that influences the quality of services provided by health professionals. The primary care teams in this study had better results in municipalities where participatory health councils acted to regulate the use of resources. However the level of professional bonus also seems to be a key motivational factor as in Mossoró, where the highest percentage of resources was earmarked for the payment of bonuses to health teams, there was a more significant improvement in performance between the two evaluation cycles analyzed.

In addition, in Natal, where a lower percentage of funds is earmarked for bonus payments, the teams performed poorly. In such circumstances, the application of significant resources to bo- 
nuses may in fact, lead to a widening of inequality in performance between poorly performing and high performing teams. In the three large municipalities studied, the teams with the best performance received a higher percentage of the PMAQ resources in the form of a bonus. Thus, it is important to conduct studies to generate knowledge about teams with lower performance in contexts of greater vulnerability. The teams with the lowest performance may find themselves in a situation of demand for more resources to provide quality services. In other words, unsatisfactory performance may be related to the collective health problems prevalent in cities with greater socioeconomic and political-institutional vulnerability. The relationship between personal reward, supporting team resources and infrastructure and social control deserves further examination.

We did not identify any other studies that have examined the role of social control in PMAQ. Therefore, in this study we sought to advance the understanding of PMAQ attributes by exploring pursuing initiatives that focus on other topics of interest, such as the satisfaction of the users of health services, as found in Abreu et al. (2018), Protasio et al. (2017a) and Protasio et al. (2017b). Although the pay-for-performance program is having positive results in Brazil, there are conflicts about how the resources are being invested that need to be considered by health managers so that social inequalities are not deepened in Brazil. For example, if the managers decide to distribute the most part of the money to teams with better performance, it needs to be clear if the health teams worked in area with the same social and economic issues. Health teams working in deprived areas may have difficulty to achieve the results.

This study indicates that the municipality with more active social control tends to achieve superior performance of the health teams in the PMAQ, once the municipality that achieved the best performance in this studied is where most part of resources was distributed as bonus to the health teams. And this distribution of the resources was possible through a law that Mossoró's Municipal Health Council articulated to approve.

What about based on our study it would seem beneficial to the Ministry of Health to indicate in the legal document that regulates PMAQ the obligation to create commissions within municipalities, with the participation of municipal health councils, in order to monitor the implementation and evaluation of the PMAQ. This could be a formal element of the process with clear regulatory guidelines about their status, their role and structure. It will also mean that some requirement is placed on municipalities to respond to the commissions and be held to account.

Such commissions may, for example, conduct local assessments to assist the municipality in meeting the goals established under the PMAQ. They may also be useful in clarifying internal disagreements in controversial points of view- as in the definition of the use of resources passed on by the Ministry of Health to the municipality. There is benefit from involving health councils in the PMAQ review process, then we suggest the Municipal Health Councils could be formal part of PMAQ evaluation.

While our study was limited to an examination of three comparative municipalities it does indicate possible problems with the current process which both confirm findings in previous studies but also highlight potential changes to the process of PMAQ and resource allocation to primary health teams. However, it would be useful to have more in-depth research on the operation of the PMAQ and its impact, the variations in the process of resource allocation and the involvement of participatory health councils and local commissions where they exist.

Research examine other regions of Brazil and municipalities of small and medium size, to increase our understanding of attributes related to the relation between participation and social control, and performance of the teams in the PMAQ. It is also suggested that such studies be carried out in municipalities with a population of less than 100,000 inhabitants in Rio Grande do Norte, to 
observe the relationship between population size, social control, and evaluation performance. Such studies need to include data from the more recent third cycle of external evaluation when results are available from the Ministry of Health.

\section{ACKNOWLEDGMENTS:}

The authors thank the Coordenação de Aperfeiçoamento de Pessoal de Nível Superior (CAPES) for the first author's doctorate sandwich scholarship at the University of Kent, UK.

\section{REFERENCES}

ABREU, D. M. X. D., ARAÚJO, L. H. L. D., REIS, C. M. R. D., LIMA, Â. M. D. L. D., SANTOS, A. D. F. D., JORGE, A. O., ... \& MACHADO, A. T. G. D. M. (2018). Percepção dos usuários sobre o cuidado prestado por equipes participantes do Programa Nacional de Melhoria do Acesso e da Qualidade da Atenção Básica no Brasil. Epidemiologia e Serviços de Saúde, 27, p.1-10. https://doi.org/10.5123/S1679-49742018000300002.

ANDRADE, M. V., NORONHA, K., BARBOSA, A. C. Q., ROCHA, T. A. H., SILVA, N. C. D., CALAZANS, J. A., ... \& SOUZA, A. (2015). A equidade na cobertura da Estratégia Saúde da Família em Minas Gerais, Brasil. Cadernos de Saúde Pública, 31, 1175-1187.

BOECKXSTAENS, P., DE SMEDT, D., DE MAESENEER, J., ANNEMANS, L., \& WILLEMS, S. (2011). The equity dimension in evaluations of the quality and outcomes framework: a systematic review. BMC health services research, 11(1), 209. https://doi.org/10.1186/1472-6963-11-209.

BOUSQUET, F., BISIAUX, R., \& CHI, Y. L. (2014). France: Payment for public health objectives. Paying for Performance in Health Care, 141.

Brasil. Law number 8142 de 1990. Social participation in the National Health System magament process, Brasília: 1990.

Brasil, A. (2016). Atlas do Desenvolvimento Humano no Brasil 2013.

Brasil. Constituição da República Federativa do Brasil. Brasília: Planalto, 2020.

CASHIN, C., \& CHI, Y. L. (2014). Australia: Practice incentives programme. Paying for Performance in Health Care, 109.

CARDOSO, A. V. L., CHAIN, A. P. N., MENDES, R. I. P., FERREIRA E FERREIRA, E., VARGAS, A. M. D., MARTINS, A. M. E. D. B. L., \& FERREIRA, R. C. (2015). Avaliação da gestão da Estratégia Saúde da Família por meio do instrumento Avaliação para Melhoria da Qualidade em municípios de Minas Gerais, Brasil. Ciência \& Saúde Coletiva, 20, 1267-1284.

CHIMARA, M. B., SILVA, E., PAIN, C., \& STOROPOLI, J. E. (2013). Gestão do Sistema de Saúde do Município de São Paulo com Base nos Parâmetros de Avaliação do PMAQ-AB: Estudo de Casos na Microrregião de Cidade Tiradentes. Revista de Gestão em Sistemas de Saúde, 2(2), 174-197.

Cidades, I. B. G. E. (2018). Instituto Brasileiro de Geografia e Estatística.

DE ALLEGRI, M., BERTONE, M. P., MCMAHON, S., CHARE, I. M., \& ROBYN, P. J. (2018). Unraveling 
PBF effects beyond impact evaluation: results from a qualitative study in Cameroon. BMJ global health, 3(2), pp. 1-8. https://doi.org/10.1136/bmjgh-2017-000693.

FISCHER, F. (2003). Reframing public policy: Discursive politics and deliberative practices. Oxford University Press.

FONTANA, K. C., LACERDA, J. T. D., \& MACHADO, P. M. D. O. (2016). O processo de trabalho na Atenção Básica à saúde: avaliação da gestão. Saúde em Debate, 40, 64-80.

KATHLEEN, E. (1989). Building theories from case study research. Academy of Management Review, 14(4), pp. 532-550. https://doi.org/10.5465/amr.1989.4308385.

GUERRA, E. M. (2005). Os controles externos e internos da administração pública. revista e ampliada. Belo Horizonte: Fórum.

GUSTAFSSON, J. (2017). Single case studies vs. multiple case studies: A comparative study.

LEMOS, L. M. A., PRADO, N. M. B. L., \& MEDINA, M. G. (2018). Programa Nacional de Melhoria do Acesso e da Qualidade da Atenção Básica (PMAQ-AB): modelização da política no âmbito nacional. Sociedade e Cultura, 21(2). https://doi.org/10.5935/0103-1104.2014S027.

LIMA, L. H. (2015). Controle externo. Grupo Gen-Editora Método Ltda.

LINHARES, P. H. A., LIRA, G. V., \& ALBUQUerque, I. M. A. N. (2014). Avaliação do Programa Nacional de Melhoria do Acesso e da Qualidade da Atenção Básica no estado do Ceará. Saúde em Debate, 38(SPE), 195-208.

MACINKO, J., HARRIS, M. J., \& ROCHA, M. G. (2017). Brazil's National Program for Improving Primary Care Access and Quality (PMAQ): fulfilling the potential of the world's largest payment for performance system in primary care. The Journal of ambulatory care management, 40 (2 Suppl), S4. https://doi.org./10.1097/JAC.0000000000000189

MATTA-MACHADO, A. T. G. D. M., SANTOS, A. D. F. D., ABREU, D. M. X. D., JORGE, A. O., REIS, C. M. R. D., LIMA, A. M. D. L. D. D., \& ARAÚJO, L. H. L. D. (2016). Asistencia sanitaria, certificación de calidad y apoyo institucional: la atención primaria en Brasil. salud pública de méxico, 58(3), 358-365.

Ministério do Planejamento, Orçamento e Gestão. (2014) Secretaria de Planejamento e Investimentos Estratégicos. Relatório Anual de Avaliação do PPA 2012-2015: ano base 2013. Ministério do Planejamento, Orçamento e Gestão. Secretaria de Planejamento e Investimentos Estratégicos. - Brasília: SPI/MP. Disponível em: <http://planejamento.gov.br/secretarias/upload/arquivo/ spi-1/ppa-1/2014-1/rel_aval_vol_2-tomo_1-sociais2013.pdf>. Acesso em: 11/11/2020

Ministry of Health of Brazil (2011). Portaria no 1654 de 19 de julho de 2011, Brasília: Ministry of Health.

PROTASIO, A. P. L., GOMES, L. B., MACHADO, L. D. S., \& VALENÇA, A. M. G. (2017). Satisfação do usuário da Atenção Básica em Saúde por regiões do Brasil: 10 ciclo de avaliação externa do PMAQ-AB. Ciência \& Saúde Coletiva, 22, pp.1829-1844. https://doi.org/10.1590/141381232017226.26472015.

PROTASIO, A. P. L., GOMES, L. B., MACHADO, L. D. S., \& VALENÇA, A. M. G. (2017). Factors 
associated with user satisfaction regarding treatment offered in Brazilian primary health care. Cadernos de saude publica, 33(2). https://doi.org/10.1590/0102-311X00184715

Rio Grande do Norte (2017). Decreto № 26.988, de junho de 2017. Natal.

SADDI, F.C., PECKHAM, S., \& DOS SANTOS MUNDIM, P. (2018). Apresentação: Pagamento por desempenho, formulação, implementação e sucesso da política em países de renda baixa, média e alta. Sociedade e Cultura, 21(2).

SADDI, F.C., \& PEGO, R. A. (2018). The collective health movement and health policy in Brazil: from regime transition/democratization to democracy and neoliberalism (1970s to 2014). Contextualizaciones Latinoamericanas, (18).

YIN, R. K. (2015). Estudo de Caso-: Planejamento e métodos. Bookman editora.

WAGSTAFF, A., \& YU, S. (2007). Do health sector reforms have their intended impacts?: The World Bank's Health VIII project in Gansu province, China. Journal of health economics, 26(3), pp.505535. https://doi.org/10.1016/j.jhealeco.2006.10.006

World Health Organization. (2018). World health statistics 2018: monitoring health for the SDGs, sustainable development goals.

World Health Organization. (2018). Declaration of Astana. Geneva: WHO. 


\section{AUTHORS}

\section{Tamiris Cristhina Resende}

Professor at the Universidade Federal de Juiz de Fora- Campus GV (UFJF/GV), Public Policy Analyst at Finance Department at the Prefeitura Municipal de Belo HorizontePh.D in Business Administration (UFRN) with a period abroad at University of Kent (United Kingdom), Master Degree in Public Administration (Joao Pinheiro Foundation), Bachelor in Business Administration (UFV).

E-mail: tamiriscristhina@gmail.com

ORCID: https://orcid.org/0000-0002-7354-2658

\section{Washington José de Souza}

Postdoctoral Researcher at Royal Holloway of the University of London (RHUL) and Birmingham Business School. Ph.D. in Education, Master Degree in Business Administration, Bachelor in Business Administration (UFRN)

E-mail: wsufrn@gmail.com

ORCID: https://orcid.org/0000-0001-6295-2806

\section{Stephen Peckham}

Director of the Centre of Health Services Studies (CHSS) at University of Kent, Professor at London School of Hygiene and Tropical Medicine

E-mail: s.peckham@kent.ac.uk

ORCID: https://orcid.org/0000-0002-7002-2614

\section{Magnus Luiz Emmendoerfer}

Associate Professor and Researcher at the Department of Administration and Accounting, Universidade Federal de Viçosa (DAD/UFV). Postdoctoral Researcher in Public Administration at University of Minho (Portugal) and in Public Policies at Tilburg University (Netherlands), PhD in Human Sciences: Sociology and Politics at the Federal University of Minas Gerais (UFMG), Master's and Bachelor's. Degree in Administration at the Federal University of Santa Catarina (UFSC)

E-mail: magnus@ufv.br

ORCID: https://orcid.org/0000-0002-4264-8644

\section{Marco Aurélio Marques Ferreira}

Associate Professor and Researcher at the Department of Administration and Accounting, Federal University of Viçosa (DAD/UFV)

Post-Doctorate in Public Administration UFRN/PGPSE/CAPES (2018-2019). Post-Doctorate in Public Administration from Rutgers University - The State University of New Jersey - USA (2011).

E-mail: marcoufv1@gmail.com

ORCID: https://orcid.org/0000-0002-9538-1699 


\section{Contribution of authors.}

Every author should account for at least one component of the work. Paper approved for publication need to specify the contribution of every single author.

\begin{tabular}{|c|c|c|c|c|c|}
\hline Contribution & [Author 1] & [Author 2] & [Author 3] & [Author 4] & [Author 5] \\
\hline 1. Definition of research problem & $\sqrt{ }$ & V & & & \\
\hline $\begin{array}{l}\text { 2. Development of hypotheses or research } \\
\text { questions (empirical studies) }\end{array}$ & $\mathrm{V}$ & $\mathrm{v}$ & & & \\
\hline $\begin{array}{l}\text { 3. Development of theoretical propositions } \\
\text { (theoretical work) }\end{array}$ & v & $v$ & $v$ & $v$ & 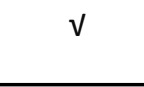 \\
\hline 4. Theoretical foundation / Literature review & $\mathrm{v}$ & $\mathrm{v}$ & $\mathrm{v}$ & $\mathrm{v}$ & $\mathrm{v}$ \\
\hline 5. Definition of methodological procedures & $\mathrm{V}$ & $\mathrm{V}$ & $\mathrm{V}$ & $\mathrm{V}$ & $\mathrm{V}$ \\
\hline 6. Data collection & $\mathrm{V}$ & & & & \\
\hline \multicolumn{6}{|l|}{ 7. Statistical analysis } \\
\hline 8. Analysis and interpretation of data & $\mathrm{v}$ & $\mathrm{v}$ & & & \\
\hline 9. Critical revision of the manuscript & $\mathrm{v}$ & $\mathrm{v}$ & $\mathrm{v}$ & $\mathrm{v}$ & $\mathrm{v}$ \\
\hline 10. Manuscript writing & $\mathrm{V}$ & $\mathrm{v}$ & $\mathrm{V}$ & $\mathrm{V}$ & $\mathrm{V}$ \\
\hline 11. Other (please specify) & & & & & \\
\hline
\end{tabular}

\section{Conflict of Interest}

The authors have stated that there is no conflict of interest.

\section{Copyrights}

ReA/UFSM owns the copyright to this content.

\section{Plagiarism Check}

The ReA/UFSM maintains the practice of submitting all documents approved for publication to the plagiarism

check, using specific tools, e.g.: CopySpider. 